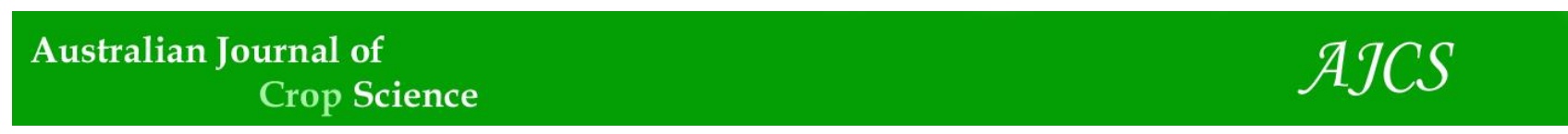

AJCS 12(05):686-698 (2018)

ISSN:1835-2707

doi: 10.21475/ajcs.18.12.05.PNE667

\title{
Oil, protein and fatty acid profiles of Brazilian soybean cultivars in multi-environmental trials
}

\author{
Gilvani Matei', Cátia Meneguzzi², Leomar Guilherme Woyann², Matheus Henrique Todeschini², Diego \\ Maciel Trevizan², Josiane Conte², Antonio Henrique Bozi², Giovani Benin²*
}

\author{
${ }^{1}$ Nidera Seeds, CEP: 85770-000, Realeza-PR, Brazil \\ ${ }^{2}$ Universidade Tecnológica Federal do Paraná- UTFPR. Câmpus Pato Branco. Via do Conhecimento, Km 1. CEP 85503- \\ 390 - Pato Branco - PR, Brazil
}

\section{*Corresponding author: benin@utfpr.edu.br}

\begin{abstract}
Soybean is an important oil and protein source for human and animal food, as well as being used in the production of biofuel. Brazilian soybean is known for its quality, especially with regard to its high protein content. This work aimed to present a screening of Brazilian soybean cropped at different locations, to assess the composition of seed with regard to the protein, oil and fatty acid contents. We screened 46 cultivars, which represent more than $50 \%$ of the soybean cultivars produced in the South-Center region of Brazil in recent years, analyzed under six environments. In order to conduct the analysis, a grain sample was used to determine seed protein, oil and fatty acid contents, which was accomplished using near infrared spectroscopy (NIR). All the traits presented a genotype $x$ environment interaction (GEI) $(p<0.01)$. A mean oil content of $20.35 \%$ was identified for all the evaluated cultivars. This was superior to that obtained in other countries. The mean protein content was $40.20 \%$, which was expected for the Brazilian soybean. This higher oil content is doubly favorable in Brazilian soybean: firstly, for its use as cooking oil and biofuel; secondly, for the production of high protein soybean meal, once all the oil is removed. The cultivars which presented the highest oil contents were also stable across the evaluated environments. On the other hand, the genotypes with the highest protein content presented low stability across the environments. Regarding the fatty acid composition, Brazilian soybean stands out for its low linoleic acid content, which gives a high oxidative stability to the resulting oil and biofuel. Trait associations were dependent on the location, thus breeders can select plants for specific traits at different locations. Brazilian cultivars present interesting characteristics for use in human and animal food products, and for biofuel production.
\end{abstract}

Keywords: Glycine max, genotype x environment interaction, GGE biplot, trait correlation, saturated and unsaturated fatty acids.

\section{Introduction}

Soybean has a high nutritional and functional value and is the main vegetal source of protein and oil. Soybean attracts attention due to its high oil ( $20 \%$ average) and protein $(40 \%$ average) content (Song et al., 2013; Medic et al., 2014). The oil and protein content of soybean seeds are receiving attention from soybean breeders, in addition to the yield (Mahmoud et al., 2006; Song et al., 2013).

With regards to nutrition, soybean is remarkable as it can supply all the essential amino acids required for human nutrition (Erdman, 2000). The quality of the soybean food products directly relies on the high amount of protein in the kernels (Stanojevic et al., 2011). Soybean is also used in animal feed through soybean meal. In this sense, the increase in grain protein content is essential for commercialization, since the international market rewards for the protein content in the soybean meal (Mourya et al., 2016).

In recent years, there has been a growing demand for alternative fuel sources. Soybean oil can be utilized as a renewable and sustainable raw material for biodiesel production (Thelen \& Ohlrogge, 2002; Clemente \& Cahoon, 2009; Day, 2013; Wu et al., 2013). In Brazil, soybean oil has traditionally been used for biofuel production (Bergmann et al., 2013), contributing $77 \%$ of the total amount of feedstock utilized for this purpose (Castanheira et al., 2015). The biodiesel produced is mixed with fossil fuel in regulated percentages according to the ANP (Brazilian Petrol, Natural gas and Biofuel Agency) resolutions. Thus, high oil content in the soybean grains is important due to both its performance in biofuel production and in food products.

Besides the importance of the total oil content, the composition of the fatty acid profile is what defines the grain's purpose. Soybean oil consists predominantly of five fatty acids: palmitic acid (C16:0), stearic acid (C18:0), oleic acid (C18:1), linoleic acid (C18:2), and linolenic acid (C18:3) (Mandarino et al., 2005; Ferrari et al., 2005; Medic et al., 2014). Palmitic and stearic acid are saturated and stable to the oxidation process, but their ingestion can cause heart diseases (Hu et al., 1997; Chowdhury et al., 2014). The oleic, linoleic and linolenic fatty acids are unsaturated, which means they may bring human health benefits. However, they are susceptible to the oxidation process, which negatively affects the stability and flavor of the oil (Crapiste et al. 1999; Santos et al., 2013; Sarkar et al., 2015). One of 
the main objectives of soybean oil composition breeding programs is a reduction in the fatty acids $18: 2$ and $18: 3$, and an increase in the fatty acids 18:1,18:0, and 16:0. These modifications increase the soybean oil quality and stability without the need for hydrogenation, making the oil suitable for human consumption (Mounts et al. 1988; Oliva et al. 2006). To produce biofuel, many of the characteristics related to the composition of fatty acid are relevant.

Soybean grain composition is strongly influenced by the genotype $x$ environment interaction (GEI) (Zhe et al., 2010; Hu \& Wiatrak, 2012; Medic et al., 2014; Hemingway et al., 2015). Environment variability in Brazil can change the behavior of the soybean crop, which affects the quantity and quality of the harvested grains. Generally, as the average temperature increases the quantity of oil increases, while the protein decreases (Wolf et al., 1982; Gunasekera et al., 2006; Naeve \& Huerd, 2008). The fatty acid profile, when tested for different environments, is also subjected to change. Under high temperatures, the grains present a higher quantity of saturated fatty acids, however, in lower temperatures there is an increase in the content of unsaturated fatty acids (Wilcox \& Cavins, 1992; Carrera et al., 2011).

The characterization of the composition of Brazilian soybean cultivars is important, as different soybean based products require a specific raw material. Thus, the objective of this study was to evaluate the protein, oil and fatty acid profile of Brazilian soybean cultivars currently cultivated in Brazil in multi-environmental trials.

\section{Results}

\section{The effect of the genotype $x$ environment interaction on soybean kernel composition}

The ANOVA indicated that there were significant effects for genotype, location and for genotype $x$ environment interaction. The GEI effects were significant for PROT $(P<0.01)$, oil $(P<0.01)$, and the fatty acids: PALM $(P<0.01)$, STE $(P<0.01)$, LIN $(P<0.01)$, LINL $(P<0.01)$, and OLE $(P<0.01)$. The mean oil content was found to be highest at PAL (21.21\%), while the lowest was found at REA (19.68\%), however, it did not differ from those found for MAB (19.86\%), SJI (20.35\%) and SMI (20.37\%) (Fig. 2A).

The highest mean PROT content was observed at MAB (42.32\%), while the lowest $(38.58 \%)$ was found at COR, however, it did not differ statistically from PAL and REA (38.87\% and $39.25 \%$, respectively) (Fig. 2A).

Among the fatty acids, PALM was found to have the highest mean at SMI (9.22\%), while the lowest means were observed at COR (8.22\%) and PAL (8.29\%). The highest mean for STE was found at PAL (3.93\%), while the lowest was found at COR (3.59\%). COR, however, did not differ significantly from REA (3.64\%) (Fig. 2B).

LIN had the highest percentage of all the fatty acids present in the soybean oil. The contents obtained at COR (51.70\%) and REA (51.35\%) were significantly different from the content obtained at SMI (49.92\%).

Mean LINL was found to be lowest at SMI (2.59\%), while the highest values were observed at REA and COR ( 4.86 and $4.76 \%$, respectively). The highest mean values for OLE were found at SI (24.72\%) and PAL (24.63\%), while the lowest mean, $21.44 \%$, was found at COR. The other fatty acids present in the soybean kernel, and not considered in this work, contributed with percentages varying from between 9.19 and $11.16 \%$, at REA and MAB, respectively (Fig. 2B).

\section{Mean and stability of grain yield and composition for} genotype through the GGE biplot

Mean and stability of oil and PROT contents, as well as the fatty acid profile, for the soybean genotypes can be visualized graphically through the GGE biplots. In the biplot graphs, the line with a single arrow head is the AEC abscissa. The AEC abscissa passes through the biplot origin and the marker for the average environment, it points towards the higher mean values. The average environment has average PC1 and PC2 scores over all the environments (Yan, 2001). The lines perpendicular to the AEC that pass through the biplot origin are referred to as the AEC ordinate. These ordinates are depicted as double-arrowed lines. The greater the absolute length of the projection of a cultivar, the less stable it is. Furthermore, the average yield of the genotypes is approximated by the projections of their markers through the AEC abscissa (Kaya et al. 2006).

The mean performance and stability of genotype grain yield (Fig. 3) showed that the cultivars NA 5909 RG (2), NS 5959 IPRO (19), M 5917 IPRO (17), M 6410 IPRO (34), NS 6767 (24), NS 6906 IPRO (22), NS 6823 RR (23), NK 7059 RR (25), 5958RSF IPRO (18), BMX Potência RR (26), NS 7000 IPRO (33), NS 7209 IPRO (35), M 6210 IPRO (45), 6563RSF IPRO (31), BMX Turbo RR (13), AS 3610 IPRO (32), 6458RSF IPRO (30), and TMG 7262 RR (27) had the highest yields, while the varieties NA 5909 RG (2), M 5917 IPRO (17), AS 3610 IPRO (32), and 6563RSF IPRO (31) besides having the highest yield also presented high stability. The cultivar BMX AtivaRR (43) presented the lowest yield among the evaluated cultivars.

The mean performance and stability of genotype oil content is presented in Figure 4. The two first principal components (PCs) explained $75.2 \%$ of the variation for this characteristic. The cultivars NA 5909 RG (2), 6563RSF IPRO (31), NS 6121RR (38), BMX AtivaRR (43), and SYN1059 RR (12) presented the highest grain oil contents. The lowest oil values were observed for the cultivars NS 6700 IPRO (37), NS 6823 RR (23), NS 6767 (24), NS 7300 IPRO (36), and NS 7209 IPRO (35). The genotypes NA 5909 RG, 6563RSF IPRO, and BMX AtivaRR presented a high oil content and were also stable across the environments. The cultivars NS 6906 IPRO and NS 7209 IPRO were stable, but presented the lowest concentration of oil among the evaluated genotypes.

Mean and stability of genotype grain yield and composition are presented through the GGE biplot, the first two PCs explained $69.3 \%$ of the variation for this characteristic (Fig. 5). The cultivars NS 7209 IPRO (35), NS 6700 IPRO (37), NK 7059 RR (25), NS 6906 IPRO (22), BMX Potência RR (26), NS 7300 IPRO (36), DMario 58i (11), NS $5290(7)$, NS 6823 RR (23), and NS 5258 (6) presented the highest protein contents. The lowest PROT contents were observed for the cultivars NS 6121RR (38), NS 6060 IPRO (39), NA 5909 RG (2), and 6563RSF IPRO (31). Three of these cultivars (6563RSF IPRO (31), NS 6121RR (38), and NA 5909 RG (2)) were among those that presented the highest oil contents. The genotypes with the highest PROT content showed, in general, low stability across the environments, with the exception of the cultivar NS 7300 IPRO (36), which combined both high protein content with a highly stable performance. 
Table 1. Evaluated cultivars with their respective code, maturity group, year of release and breeding company.

\begin{tabular}{|c|c|c|c|c|}
\hline Code & Cultivar & $\begin{array}{l}\text { Maturity } \\
\text { group }\end{array}$ & Year of release & Released by \\
\hline 1 & NS 5000 IPRO & 5 & 2012 & Nidera \\
\hline 2 & NA 5909 RG & 5.9 & 2008 & Nidera \\
\hline 3 & NS 5151 IPRO & 5.1 & 2012 & Nidera \\
\hline 4 & NS 4823 & 4.8 & 2008 & Nidera \\
\hline 5 & NS 5858 & 5.8 & 2010 & Nidera \\
\hline 6 & NS 5258 & 5.2 & 2012 & Nidera \\
\hline 7 & NS 5290 & 5.2 & 2012 & Nidera \\
\hline 8 & NS 4901 & 4.9 & 2012 & Nidera \\
\hline 9 & BMX Energia RR & 5.3 & 2008 & GDM GENÉTICA \\
\hline 10 & NS 6262 & 6.2 & 2010 & Nidera \\
\hline 11 & DMario 58i & 5.5 & 2007 & GDM GENÉTICA \\
\hline 12 & SYN1059 RR & 5.9 & 2010 & Syngenta \\
\hline 13 & BMX Turbo RR & 5.8 & 2009 & GDM GENÉTICA \\
\hline 14 & NS 5445 IPRO & 5.4 & 2012 & Nidera \\
\hline 15 & NS 6006 IPRO & 6 & 2013 & Nidera \\
\hline 16 & NS 5727 IPRO & 5.7 & 2013 & Nidera \\
\hline 17 & M 5917 IPRO & 5.9 & 2012 & MONSOY \\
\hline 18 & 5958RSF IPRO & 5.8 & 2012 & GDM GENÉTICA \\
\hline 19 & NS 5959 IPRO & 5.9 & 2012 & Nidera \\
\hline 20 & TMG 2158 IPRO & 5.8 & 2013 & TMG \\
\hline 21 & AS 3570IPRO & 5.7 & 2012 & MONSOY \\
\hline 22 & NS 6906 IPRO & 6.9 & 2013 & Nidera \\
\hline 23 & NS 6823 RR & 6.8 & 2013 & Nidera \\
\hline 24 & NS 6767 & 6.7 & 2011 & Nidera \\
\hline 25 & NK 7059 RR & 6.2 & 2007 & Syngenta \\
\hline 26 & BMX Potencia RR & 6.7 & 2007 & GDM GENÉTICA \\
\hline 27 & TMG 7262 RR & 6.2 & 2011 & TMG \\
\hline 28 & NS 6209 & 6.2 & 2012 & Nidera \\
\hline 29 & NS 6909 IPRO & 6.9 & 2012 & Nidera \\
\hline 30 & 6458RSF IPRO & 6 & 2012 & GDM GENÉTICA \\
\hline 31 & 6563RSF IPRO & 6.3 & 2012 & GDM GENÉTICA \\
\hline 32 & AS 3610 IPRO & 6.1 & 2012 & MONSOY \\
\hline 33 & NS 7000 IPRO & 7 & 2012 & Nidera \\
\hline 34 & M 6410 IPRO & 6.4 & 2011 & MONSOY \\
\hline 35 & NS 7209 IPRO & 7.2 & 2012 & Nidera \\
\hline 36 & NS 7300 IPRO & 7.3 & 2012 & Nidera \\
\hline 37 & NS 6700 IPRO & 6.7 & 2013 & Nidera \\
\hline 38 & NS 6121RR & 6.1 & 2013 & Nidera \\
\hline 39 & NS 6060 IPRO & 6 & 2013 & Nidera \\
\hline 40 & NS 7338 IPRO & 7.3 & 2012 & Nidera \\
\hline 41 & NS 7237 IPRO & 7.2 & 2012 & Nidera \\
\hline 42 & NS 5401RR & 5.4 & 2012 & Nidera \\
\hline 43 & BMX AtivaRR & 5.6 & 2008 & GDM GENÉTICA \\
\hline 44 & A 6411RG & 6.4 & 2008 & Nidera \\
\hline 45 & M 6210 IPRO & 6.2 & 2011 & MONSOY \\
\hline 46 & NS 5106 IPRO & 5.1 & 2012 & Nidera \\
\hline
\end{tabular}

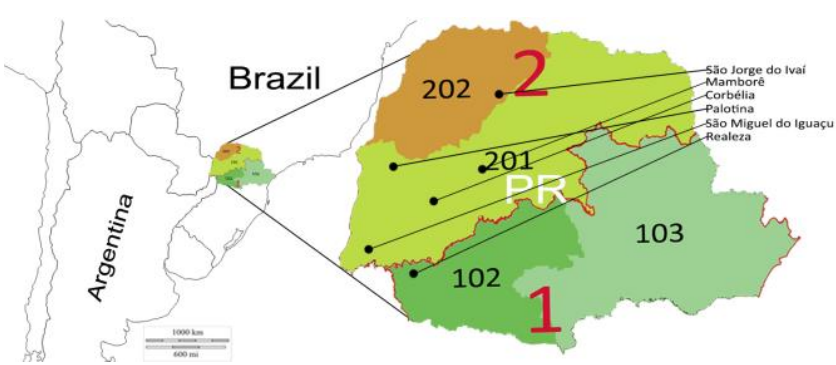

Fig 1. Test locations and their respective macro-regions (1 and 2) and microregions (102, 103, 201, and 202) of adaptation of soybean in Brazil. SJI: São Jorge do Ivaí; MAB: Mamborê; PAL: Palotina; COR: Corbélia; SMI: São Miguel do Iguaçu; REA: Realeza. 
Table 2. Description of the six cultivation sites located in the South region of Brazil.

\begin{tabular}{lllll}
\hline Location & Code & Latitude & Longitude & Altitude \\
\hline Corbélia & COR & $24^{\circ} 47^{\prime} \mathrm{S}$ & $53^{\circ} 18^{\prime} \mathrm{W}$ & $650 \mathrm{~m}$ \\
Mamborê & $\mathrm{MAB}$ & $24^{\circ} 19^{\prime} \mathrm{S}$ & $52^{\circ} 31^{\prime} \mathrm{W}$ & $715 \mathrm{~m}$ \\
Palotina & $\mathrm{PAL}$ & $24^{\circ} 17^{\prime} \mathrm{S}$ & $53^{\circ} 50^{\prime} \mathrm{W}$ & $330 \mathrm{~m}$ \\
Realeza & $\mathrm{REA}$ & $25^{\circ} 46^{\prime} \mathrm{S}$ & $53^{\circ} 31^{\prime} \mathrm{W}$ & $520 \mathrm{~m}$ \\
São Jorge do Ivaí & $\mathrm{SJI}$ & $23^{\circ} 25^{\prime} \mathrm{S}$ & $52^{\circ} 17^{\prime} \mathrm{W}$ & $560 \mathrm{~m}$ \\
São Miguel do Iguaçu & $\mathrm{SMI}$ & $25^{\circ} 20^{\prime} \mathrm{S}$ & $54^{\circ} 14^{\prime} \mathrm{W}$ & $290 \mathrm{~m}$ \\
\hline
\end{tabular}

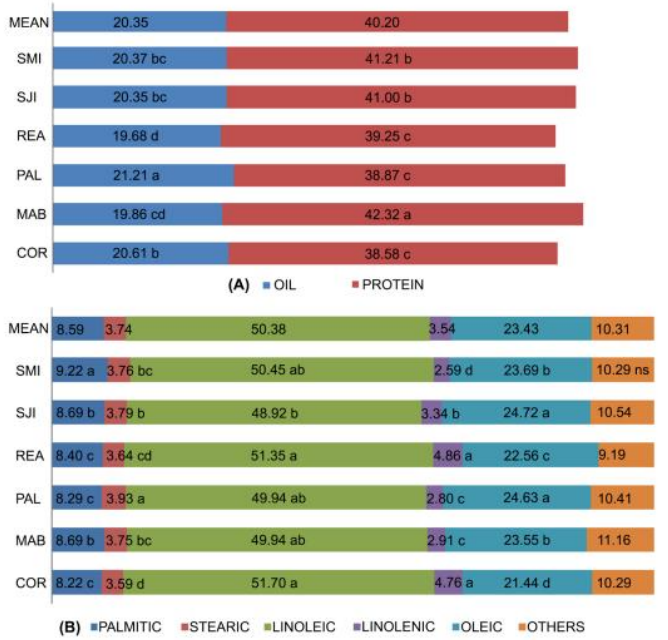

Fig 2. Protein, oil and fatty acids of 46 soybean genotypes evaluated in six locations. A) Mean oil and protein content for each location and for all the locations combined. B) Fatty acid content for each location and for the mean of all the locations. SMI, São Miguel do Iguaçu; SJI, São Jorge do Ivaí; REA, Realeza; PAL, Palotina; MAB, Mamborê; and COR, Corbélia.

Table 3. Pearson coefficient of correlation for grain yield (GY), protein (PROT), oil and the fatty acids palmitic (PALM), linoleic (LIN), linolenic (LINL), oleic (OLE) and stearic (STE).

\begin{tabular}{|c|c|c|c|c|c|c|c|}
\hline & COR & MAB & PAL & REA & SJI & SMI & Mean \\
\hline GY $\times$ OIL & -0.17 & 0.14 & -0.19 & $0.32 *$ & 0.08 & $-0.29 *$ & -0.14 \\
\hline GY x PROT & $0.43 * *$ & -0.19 & $0.65 * *$ & $-0.33 *$ & -0.17 & $0.33^{*}$ & 0.20 \\
\hline GY $\times$ PALM & $0.34 *$ & 0.00 & -0.04 & $-0.40 * *$ & -0.18 & 0.06 & 0.05 \\
\hline GY x LIN & $-0.30 *$ & 0.08 & -0.13 & $0.39 * *$ & $0.33 *$ & -0.07 & 0.15 \\
\hline GY $\times$ LINL & 0.21 & 0.06 & -0.03 & -0.13 & 0.01 & 0.14 & 0.13 \\
\hline GY $\times$ OLE & 0.18 & 0.02 & 0.26 & -0.13 & $-0.31 *$ & -0.11 & -0.08 \\
\hline GY x STE & 0.11 & 0.19 & 0.09 & -0.26 & -0.15 & 0.13 & 0.03 \\
\hline OIL x PROT & $-0.51 * *$ & $-0.60 * *$ & $-0.47 * *$ & $-0.62 * *$ & $-0.34 *$ & $-0.48 * *$ & $-0.70 * *$ \\
\hline OIL x PAL & -0.13 & $-0.34 *$ & -0.14 & $-0.50 * *$ & -0.20 & $-0.52 * *$ & $-0.40 * *$ \\
\hline OIL x LIN & 0.12 & 0.06 & 0.01 & 0.16 & 0.12 & $0.33 *$ & 0.00 \\
\hline OIL x LINL & $-0.46 * *$ & $-0.36 *$ & $-0.38 * *$ & $-0.34 *$ & -0.25 & $-0.52 * *$ & $-0.49 * *$ \\
\hline OIL x OLE & $0.41 * *$ & 0.25 & $0.31 *$ & 0.24 & 0.18 & $0.45 * *$ & $0.54 * *$ \\
\hline OIL x STE & $0.34 *$ & $0.40 * *$ & 0.24 & 0.22 & 0.10 & 0.12 & $0.29 *$ \\
\hline PROT $x$ PALM & -0.03 & 0.13 & -0.11 & 0.28 & -0.12 & -0.04 & 0.19 \\
\hline PROT x LIN & $-0.41 * *$ & $-0.29 *$ & -0.20 & $-0.44 * *$ & -0.22 & -0.12 & -0.17 \\
\hline PROT $x$ LINL & 0.01 & -0.08 & -0.05 & 0.08 & 0.15 & -0.02 & 0.16 \\
\hline PROT $\times$ OLE & 0.23 & 0.13 & 0.16 & $0.35 *$ & $0.32 *$ & 0.07 & -0.07 \\
\hline PROT $x$ STE & 0.04 & -0.14 & 0.07 & 0.13 & -0.11 & 0.09 & -0.07 \\
\hline PALM x LIN & $-0.29 *$ & -0.09 & -0.13 & -0.26 & $-0.56 * *$ & $-0.53 * *$ & $-0.47 * *$ \\
\hline PALM $x$ LINL & 0.24 & $0.33 *$ & -0.08 & 0.27 & -0.01 & $0.40 * *$ & 0.16 \\
\hline PALM $\times$ OLE & $-0.37 *$ & -0.27 & -0.15 & -0.17 & 0.03 & -0.29 & -0.12 \\
\hline PALM $\times$ STE & 0.15 & -0.08 & 0.26 & 0.28 & 0.18 & 0.02 & 0.22 \\
\hline LIN x LINL & -0.10 & 0.23 & 0.14 & -0.24 & 0.14 & -0.19 & 0.01 \\
\hline LIN $\times$ OLE & $-0.38 * *$ & $-0.74 * *$ & $-0.58 * *$ & $-0.66 * *$ & $-0.58 * *$ & -0.28 & $-0.60 * *$ \\
\hline LIN x STE & -0.27 & $-0.47 * *$ & -0.25 & $-0.34 *$ & -0.22 & $-0.29 *$ & $-0.37 *$ \\
\hline LINL $\times$ OLE & $-0.44 * *$ & $-0.63 * *$ & $-0.35 *$ & $-0.31 *$ & $-0.53 * *$ & $-0.72 * *$ & $-0.56 * *$ \\
\hline LINL x STE & $-0.52 * *$ & $-0.60 * *$ & $-0.65 * *$ & $-0.37 *$ & $-0.68 * *$ & $-0.64 * *$ & $-0.64 * *$ \\
\hline OLE x STE & $0.53 * *$ & $0.72 * *$ & $0.54 * *$ & $0.42 * *$ & $0.51 * *$ & $0.73 * *$ & $0.64 * *$ \\
\hline
\end{tabular}

** and ${ }^{*}$, significant at $1 \%$ and $5 \%$ by $t$ test. COR: Corbélia, MAB: Mamborê, PAL: Palotina, REA: Realeza, SJI; São Jorge do Ivaí, SMI: São Miguel do Iguaçu. 


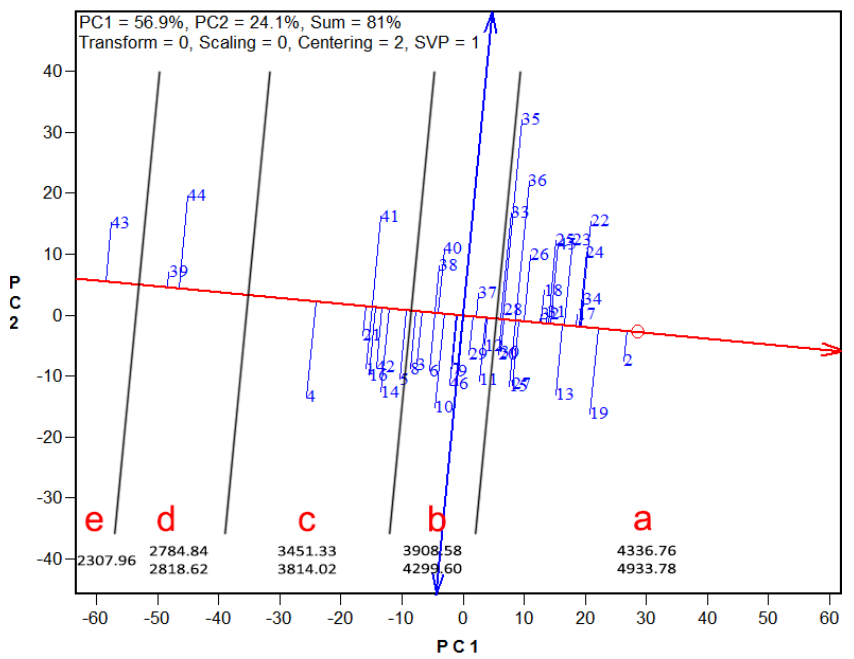

Fig 3. GGE biplot for mean productivity and stability, mean clustering via Scott-Knott and the value limits for each cluster of grain yield for 46 Brazilian soybean genotypes cultivated at six locations during the 2014/2015 growing season. PC, principal component; SVP, singular value partitioning method.

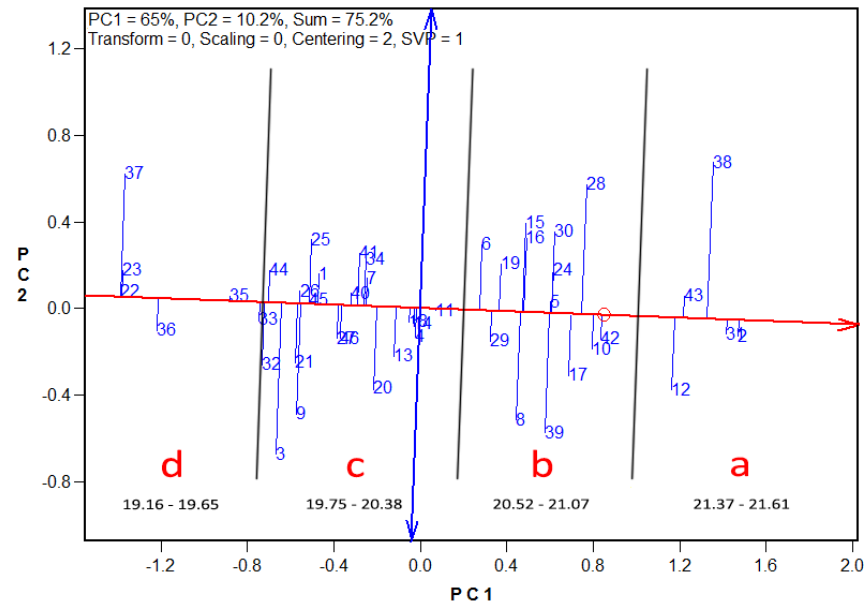

Fig 4. GGE biplot for mean and stability, mean clustering via Scott-Knott and the value limits for each cluster for oil content for 46 Brazilian soybean genotypes cultivated at six locations during the $2014 / 2015$ season. PC, principal component; SVP, singular value partition method.

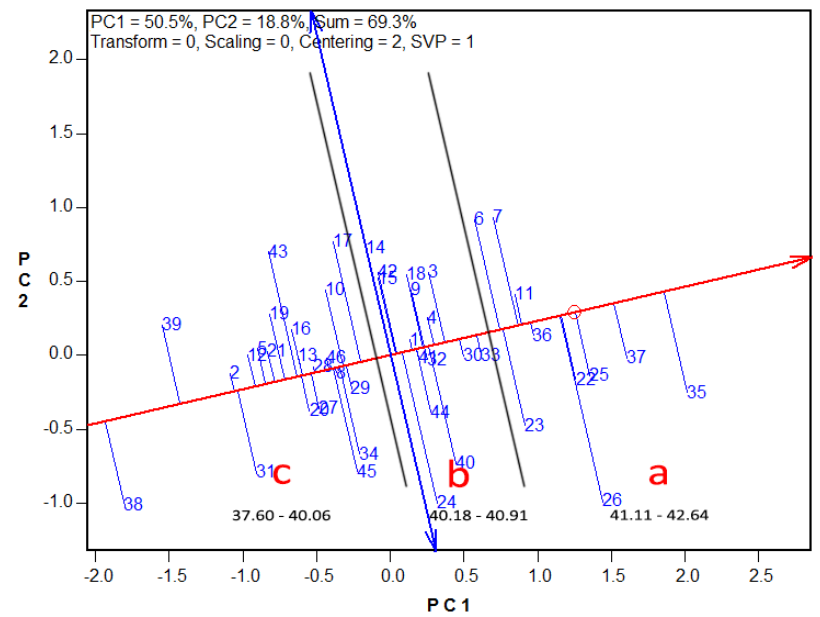

Fig 5. GGE biplot for mean performance and stability, mean clustering via Scott-Knott and the value limits for each cluster for protein content for 46 Brazilian soybean genotypes cultivated at six locations during the 2014/2015 season. PC, principal component; SVP, singular value partition method. 


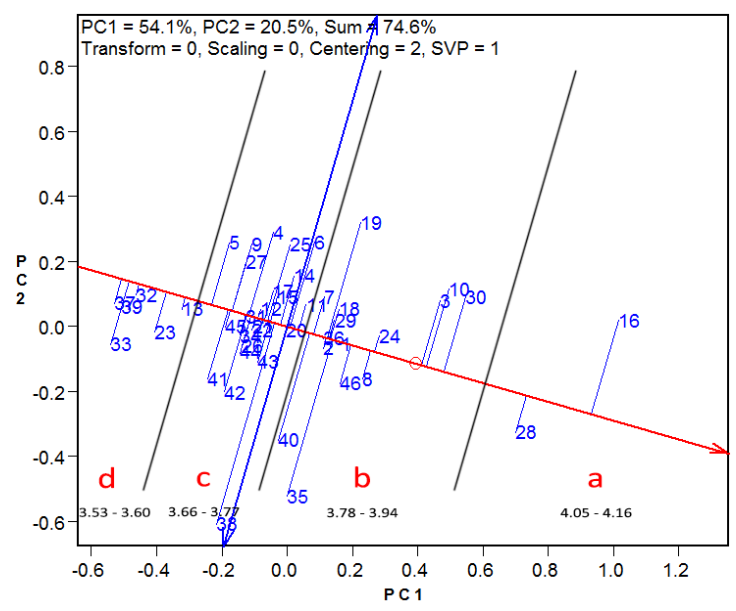

Fig 6. GGE biplot for mean performance and stability, mean clustering via Scott-Knott and the value of limits for each cluster for stearic fatty acid content for 46 Brazilian soybean genotypes cultivated at six locations during the 2014/2015 season. PC, principal component; SVP, singular value partition method.

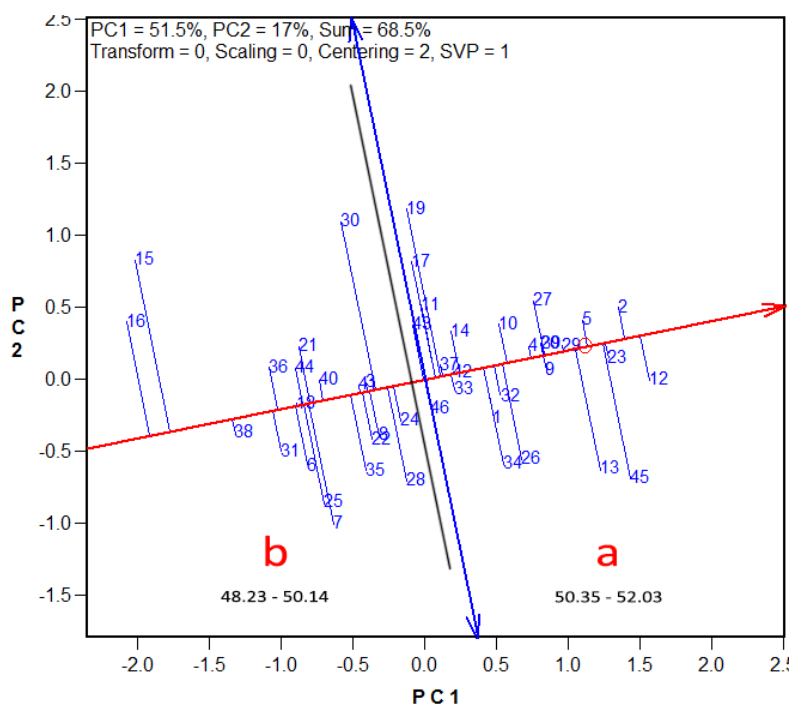

Fig 7. GGE biplot for mean performance and stability, mean clustering via Scott-Knott and the value limits for each cluster of linoleic fatty acid content for 46 Brazilian soybean genotypes cultivated at six locations during the 2014/2015 season. PC, principal component; SVP, singular value partition method.

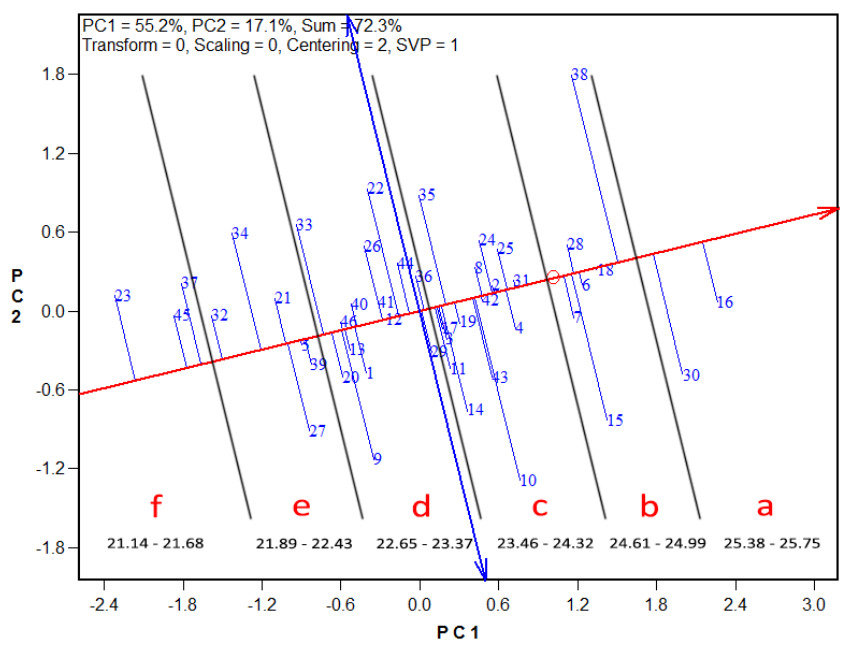

Fig 8. GGE biplot for mean performance and stability, mean clustering via Scott-Knott and the value limits for each cluster for oleic fatty acid content for 46 Brazilian soybean genotypes cultivated at six locations during the 2014/2015 season. PC, principal component; SVP, singular value partition method. 


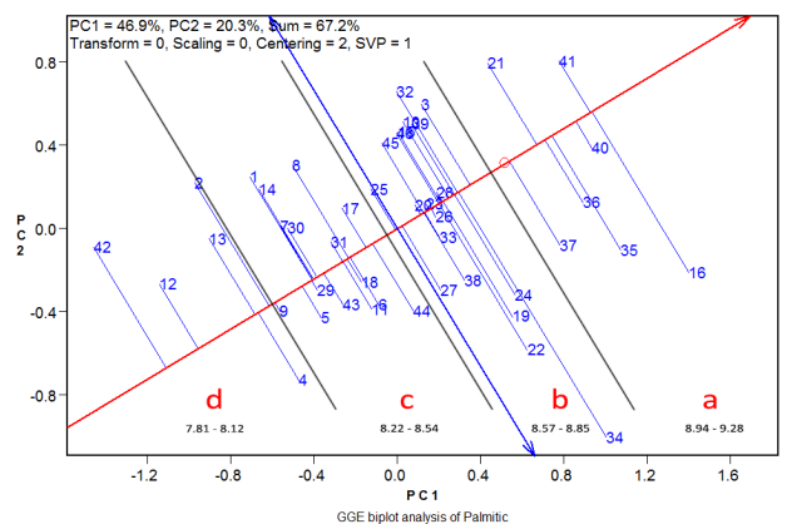

Fig 9. GGE biplot for mean performance and stability, mean clustering via Scott-Knott and the value limits for each cluster of palmitic fatty acid content for 46 Brazilian soybean genotypes cultivated at six locations during the 2014/2015 season. PC, principal component; SVP, singular value partition method.

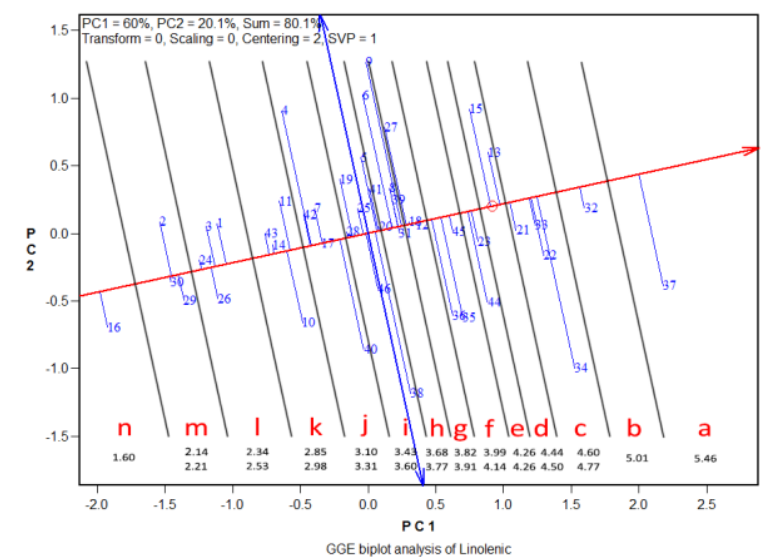

Fig 10. GGE biplot for mean performance and stability, mean clustering via Scott-Knott and the value limits for each cluster of linolenic fatty acid content for 46 Brazilian soybean genotypes cultivated at six locations during the 2014/2015 season. PC, principal component; SVP, singular value partition method.

Figure 6 allows the visualization of the graphical representation of the mean performance and stability of the genotypes regarding the fatty acid STE. The PCs 1 and 2 explained $74.6 \%$ of the total variation. The cultivars NS 5727 IPRO (16), and NS 6209 (28) presented the highest STE fatty acid content. On the other hand, the varieties NS 6700 IPRO (37), NS 6060 IPRO (39), NS 7000 IPRO (33), AS 3610 IPRO (32), NS 6823 RR (23), and BMX Turbo RR (13) had the lowest contents. The genotype NS 6209 (28) was shown to be stable in the evaluated environments. However, the AS 3610 IPRO (32), and BMX Turbo RR (13) genotypes had low contents of this fatty acid, but were shown to be stable in the environments.

The mean performance and stability of the fatty acid LIN can be observed for the gynotypes in Figure 7. The two PCs explained $68.5 \%$ of the total variation. The cultivars were divided into two groups. The high concentration grouping containing the cultivars SYN1059 RR (12), NA 5909 RG (2), NS 6823 RR (23), M 6210 IPRO (45), and NS 5858 (5). In contrast, the NS 6006 IPRO (15) and NS 5727 IPRO (16) cultivars presented the lowest LIN acid contents. Among the genotypes with the highest LIN acid content, the NS 6823 RR (23) and NS 6909 IPRO (29) genotypes were the most stable. Regarding the genotypes with the lowest LIN acid contents, NS 6121RR (31) and 5958RSF IPRO (18) were the most stable.
For OLE acid, it is possible to note that the two PCs accounted for $72.3 \%$ of the total variation (Fig. 8). The NS 5727 IPRO (16) and 6458RSF IPRO (30) cultivars had the highest content of this acid, while the NS 6823 RR (23), M 6210 IPRO (45) and NS 6700 IPRO (37) genotypes had the lowest content. The genotypes with the highest OLE acid contents were not observed as being stable. However, among the genotypes with concentrations superior to the overall mean 5958RSF IPRO (18) and NS 5258 (6) were stable in the evaluated environments. In contrast, among the cultivars with the lowest OLE contents, the genotypes NS 5858 (5) and NS 5106 IPRO (46) were stable.

The biplot graphic for PALM acid is presented in Figure 9. It was observed that the two PCs represented $67.2 \%$ of the total variation. The cultivars NS 5727 IPRO (16), NS 7237 IPRO (41), NS 7338 IPRO (40), NS 7209 IPRO (35), NS 7300 IPRO (36), AS 3570IPRO (21), and NS 6700 IPRO (37) presented the highest content of this fatty acid, while the cultivars NS 5401RR (42), SYN1059 RR (12), BMX Turbo RR (13), NS 4823 (23) and NA 5909 RG (2) had the lowest means. Among the genotypes with the highest PALM acid contents, the genotype NS 7338 IPRO (40) was the most stable. For the genotypes with the lowest contents, none were observed to present high stability. The variety BMS Energia RR (9), which was stable, had an inferior PALM acid concentration than the overall mean. 
The biplot for the LINL acid content is shown in Figure 10. The two PCs represented $80.1 \%$ of the total variation. The highest LINL acid content was obtained for the NS 6700 IPRO (37) cultivar. In contrast, the NS 5727 IPRO (16) cultivar presented the lowest content. These genotypes were not stable. The AS 3610 IPRO (32) and 6458RSF IPRO (30) genotypes were the most stable from the high and low LINL acid content groups, respectively.

\section{Trait association}

There were large variations in magnitude, significance, and direction, i.e. positive and negative, for the associations among the traits (Table 3). For GY $\times$ PROT, the correlations varied from $0.65^{* *}$ in PAL to $-0.33^{*}$ in REA. For GY $\times$ OIL, the correlation changed from $0.32 *$ at REA to -0.29 at SMI. In general, the positive association among GY $x$ PROT resulted in a negative association between GY $\times$ OIL, under the same environment. STE and LINL acid did not correlate with yield for any of the evaluated environments. LIN acid had a significant correlation with yield at COR $\left(-0.30^{*}\right)$, REA $\left(0.39^{* *}\right)$, and $\mathrm{SJ}\left(0.33^{*}\right)$. The correlation for yield $\mathrm{x}$ OLE was significant only for the SJI (-0.31*) environment.

The correlation between oil x PROT varied between -0.62 (REA) and -0.34* (SJI). The oil content also presented significant correlations, for the environmental average, with PALM, LINL, and OLE acid, with values of $-0.40 * *,-0.49 * *$, and $0.54^{* *}$, respectively. For the environmental average, the percentage of protein did not show a significant correlation for any of the fatty acids.

Through the environmental average, some fatty acids had significant correlations among themselves. LIN acid had a significant correlation with PALM, OLE, and STE acid, with values of $-0.47^{* *},-0.56 * *$, and $-0.37 *$, respectively. LINL acid had a significant association with the OLE and STE acid, with values of $-0.56 * *$ and $-0.64 * *$, respectively. The OLE acid was positively correlated with stearic acid for the overall mean of environments $\left(0.64^{* *}\right)$. For the significant correlations among fatty acids, at some of the environments, the interaction was not significant, however, the direction of the correlation was not altered.

\section{Discussion}

\section{Environmental effect on grain composition}

The ANOVA indicated the presence of a GEI for all the evaluated Traits, showing that the concentrations of protein, oil, and the fatty acids significantly respond to environmental variation. These results are in accordance with other studies (Kumar et al., 2006; Hemingway et al., 2015; Bellaloui et al., 2015; Song et al., 2016).

Besides the genotype, crop management and biotic and abiotic factors such as sowing date, temperature, water conditions, soil conditions, agronomical practices, and disease severity can also affect the composition of the grains (Dardanelli et al., 2006; Bellaloui et al., 2009; Bellaloui et al., 2015; Lee et al., 2015). Generally, the protein content of soybean is increased when the crop is grown under moderate water stress and high temperatures during the grain filling phase (Vollmann et al., 2000; Rotundo \& Westgate, 2009; Rotundo et al., 2014). Lower protein contents, on the other hand, may be the result of normal or above normal water supply and mild temperatures. Besides this, Pípolo (2002) observed that soybean grain protein tended to increase with increasing altitude.

The mean crude PROT content in this work was $40.20 \%$. Grieshop \& Fahey Jr (2001) obtained a PROT content of $40.30 \%$ for soybean produced in Paraná State - Brazil, in an area similar to those utilized in this study. Karr-Lilienthal et al. (2004) found PROT to be $39.3 \%$, which corroborated the results from our work. Our results indicated that altitude was the observed parameter that differentiated the study locations, with regard to the grain protein content. The highest PROT content was obtained at MAB, which was the environment with the highest altitude (Table 2).

The mean oil content observed was $20.34 \%$. There was a significant difference between the environments, with the lowest values found at REA (19.68\%), while the highest values were at PAL (21.21\%). The oil contents found for these two sites were higher than those found in other studies. Grieshop \& Fahey Jr (2001) obtained oil contents for Brazilian soybean that varied between $18.02 \%$ and $19.75 \%$ for different Brazilian states. These authors found oil contents to be considerably lower in Chinese soybean. Other studies have associated high temperatures with soybean grain oil quantity (Wolf et al., 1982; Naeve and Huerd, 2008). The environment PAL was found to provide the highest oil content among all the environments. This is explained by the high temperatures during the grain filling phase. On the other hand, the environment REA provided inferior oil content, which was a consequence of the lower temperatures during this phase.

In this study, the average PALM acid contents accounted for $8.58 \%$ of the total oil content. These levels were lower than the $12 \%$ considered normal for soybean by Wilson et al. (2002) and Fehr (2007). Studies involving Brazilian soybean cultivars demonstrate that it presents lower values than those considered normal for this fatty acid (Santos et al., 2013; Priolli et al., 2015). Nevertheless, specific breeding programs that aim to develop cultivars with differentiated contents of this fatty acid pointed out that genetic modifications have been conducted for the development of genotypes with a lower content $(<4 \%$ ) of PALM (Stoltzfus et al., 2000). The normal STE fatty acid content in soybean grains is approximately $4 \%$ (Wilson et al., 2002). In this study, the mean content of stearic acid for the environments combined was $3.74 \%$, with values varying from $3.64 \%$ (REA) to $3.93 \%$ (PAL). Similar results were found by Priolli et al. (2015), who obtained means of $3.2 \%$ for Brazilian soybean genotypes.

Unsaturated fatty acids differ in their degree of unsaturation. 18:1 is monounsaturated, while 18:2 and 18:3 are polyunsaturated fatty acids. The mean $18: 2$ content was $50.38 \%$ and it varied from $48.92 \%$ (SJI) to $51.7 \%$ (COR). The mean values observed in our study were similar to those obtained by both Vieira et al., 1990 and Priolli et al., 2015. We observed that the Brazilian genotypes had lower levels than those considered appropriate ( $\geq 54 \%$ ) according to Wilson (2004), but within the range of 48 to $58 \%$ indicated by Bellaloui et al. (2015). The content level considered normal for the fatty acid LINL is $8 \%$, according to Wilson (2004). In our study, the mean for this trait was $3.54 \%$ and it varied from $2.59 \%$ (SMI) to $4.86 \%$ (REA). This indicates that the Brazilian soybean genotypes present, on average, a low LINL content (3-6\%). These results were lower than those 
found by Priolli et al. (2015), who observed a mean content of $6.0 \%$. However, these authors analyzed material obtained from genebanks, which tend to have a greater range of values, and thus increase the average. Soybean cultivars contain roughly $22 \%$ OLE fatty acid (Wilson, 2002). In our study, the mean for this trait was of $23.4 \%$ and the values varied from $21.44 \%$ (COR) to $24.72 \%$ (SJ). These data agree with those found by Priolli et al. (2015) for Brazilian soybean genotypes.

The composition of fatty acids can be influenced by temperature (Wolf et al 1982; Cheesbrough, 1989; Tang et al., 2005; Medic et al., 2014). Studies conducted by Ren et al. (2009) and Carrera et al. (2011) showed that high temperatures during seed development significantly increased the total oil content, and the contents of the fatty acids OLE, PALM, and STE, however, the contents of LIN and LINL decreased. In our study, the environment PAL, which has a higher mean temperature, presented the highest contents of oil, STE and OLE.

\section{Cultivars and their protein, oil and fatty acid quality}

The GGE biplot methodology has been widely used to analyze genotype $x$ environment interactions. This methodology has been used in genotype stability and adaptability analysis, to verify the formation of megaenvironments and to identify discriminant and representative environments, among other characteristics of relevance to plant breeders (Yan et al., 2007; Lado et al., 2015; Sharma et al., 2016). In this work, the GGE methodology was used to identify genotypes with high stability and superior agronomical performance for the evaluated traits.

The results show that there was differentiation among evaluated genotypes for all the studied variables. Grain yield is one of the main parameters observed when selecting a cultivar. In this sense, the variety NA 5909 RG (2) has a high productivity concomitantly with a high oil content and phenotypic stability for most of the evaluated variables. The genotypes that had the lowest oil content (NS 6700 IPRO (37), NS 6823 RR (23), NS 6906 IPRO (22), NS 7300 IPRO (36), and NS 7209 IPRO (35)) were those that presented the highest PROT contents. Similarly, the varieties that presented the highest oil contents also had the lowest quantity of protein (NS 6121RR (38), NA 5909 RG (2), 6563RSF IPRO (31), and BMX AtivaRR (43)). This explains the negative correlation between these traits, thus, among the studied variables there were no cultivars presenting high contents of both oil and protein. This behavior has also been observed by other authors (Clemente \& Cahoon, 2009; Wittkop et al., 2009; Popovic et al., 2012).

One of the main objectives of a soybean oil composition breeding program is the reduction of the fatty acids $18: 2$ and 18:3 and an increase in 18:1,18:0, and 16:0 when looking for characteristics related to the oxidative stability of oils (Mounts et al. 1988; Oliva et al. 2006). The genotype NS 5727 IPRO (16) presented high oil oxidative stability potential. This cultivar had a high saturated fatty acid and a low polyunsaturated content, which confers high stability to the oil. However, this variety had an average yield that resulted in it not being among the most productive cultivars. When the soybean is intended mainly for human consumption, a low content of saturated fatty acids is ideal, because high contents of these fatty acids increase cholesterol, raising the risk of heart disease. The cultivar BMX Turbo RR (13) presented a high grain yield and low saturated fatty acid content. This composition is appropriate when its grains are used for the production of food. Moreover, soybean grains high in 16:0 and 18:0 can be used for high cetane number $(\mathrm{CN})$ biofuel production.

\section{Correlations are dependent on location}

Correlation analysis can provide gains in plant breeding, as it helps determine the selection strategy and make the selection process less time consuming, further to this, it can reduce the physical space and financial resources used by the breeding program. In our study, the association among traits was strongly influenced by the environment (Tab. 3). For the average correlation, the traits GY $x$ OIL and GY $x$ PROT did not show a significant association. However, the associations varied when analyzed in different environments. REA had a significant positive association between GY $\times$ OIL, and a significant negative correlation for $\mathrm{GY} \times \mathrm{PROT}$. For the SMI environment the correlation among GY $\times$ OIL was negative, while GY $\times$ PROT was positive. When correlations are constant through the years, breeders can perform plant selections in environments where the desired parameters are simultaneously present. If the breeding program's objective is to find a high protein concentration, the SMI location would be ideal for plant selection, thus, genotypes with high grain yield will also have high protein content. Likewise, if the objective is high oil content, plant selection could be performed at REA, this way genotypes with a high productivity would also possess high oil content, simultaneously.

The GY was not correlated with any of the traits in this study in the joint analysis for the six locations. These results corroborate with Popović et al. (2012) and Bonato et al. (2000) who did not find a significant correlation between GY $x$ PROT and GY x OIL. Many authors have demonstrated a negative correlation between GY x PROT (Thorne \& Fehr, 1970; Hartwig \& Hinson, 1972; Hymowitz et al., 1972; Voldeng et al., 1997; Wilcox \& Guodong, 1997). Others have shown a positive association between PROT and GY (Kwon \& Torrie, 1964; Simpson Junior \& Wilcox, 1983).

For the associations between OIL $x$ PROT, LIN x OLE, LINL $x$ OLE, LINL $\times$ STE, and OLE $\times$ STE the correlations were consistent for every environment and for the general mean. There was a significant negative association between oil content and protein. Thus, whenever the oil content is desired in a breeding program, the protein is reduced. The inverse association between soybean oil and protein is well documented (Johnson et al., 1955; Bonato et al., 2000; Clemente \& Cahoon, 2009; Wittkop et al., 2009; Popovic et al., 2012). Normally, when the oil content decreases by $1 \%$, the protein content is increased by $2 \%$ (Clemente \& Cahoon, 2009).

There was a significant negative correlation between oleic fatty acid and the polyunsaturated fatty acids. These data corroborate with other studies (Kumar et al., 2006; Lee et al., 2007; Bachlava et al., 2008; Song et al., 2013). The negative correlation between OLE and LIN can be understood since linoleic acid is formed by the oxidative denaturation of oleic, and therefore, when the LIN content is enhanced OLE acid is reduced (Zhang et al., 2015). STE fatty 
acid had a significant negative correlation with LINL acid and a positive correlation with OLE. Zhang et al. (2015) found similar results regarding the correlation between STE and 18:3, however, the correlation with 18:1 was negative. The positive association between oleic and stearic acid can make it difficult to obtain genotypes that present ideal fatty acid composition characteristics.

\section{Materials and Methods}

\section{Plant materials}

We evaluated forty-six Brazilian soybean cultivars that are widely cultivated in the Center-South region of Brazil. The cultivars were released between 2007 and 2013 (Table 1). The cultivars came from the breeding companies Nidera, Monsanto, Dom Mario Group, Syngenta, and TMG, which run the major soybean breeding programs in Brazil. The maturity groups for the Brazilian soybean were inspired by the American method, meaning that the genotypes with lower maturity groups are adapted to locations at higher latitudes.

\section{Locations}

The experiments were conducted at six locations in the state of Paraná - Brazil (Figure 1 and Table 2), all of which classified as climate type Cfa (Köppen-Geiger) (Peel et al., 2007).

\section{Experimental design}

The experiments were conducted in a randomized complete block design, with three replications. The experimental units consisted of four lines of five meters, with a $0.5 \mathrm{~m}$ row spacing. The sowing rate was 30 seeds $\mathrm{m}^{-2}$ and there was a base fertilization of $350 \mathrm{~kg} \mathrm{ha}^{-1}$ of NPK (02-20-20). The crop treatments were performed in accordance with their technical recommendations.

\section{Evaluation of traits related to grain yield and quality composition}

The yield, in $\mathrm{kg} \mathrm{ha}^{-1}$, was obtained by harvesting the two central lines ( $5 \mathrm{~m}^{2}$ of useful area). A sample of the harvested kernels was used to determine the protein (PROT), oil, palmitic acid (PALM), stearic acid (STE), oleic acid (OLE), linoleic acid (LIN), and linolenic acid (LINL) contents. These analyses were conducted by near infrared spectroscopy (NIR), using a Foss XDS-NIR Rapid Content Analyzer (FOSS Analytical, Slangerupgade, Denmark). The NIR spectral data were collected between 400 and 2,500 nm at $2 \mathrm{~nm}$ intervals. Mathematical procedures on the spectral information were carried out as described by Han et al. (2014).

\section{Statistical analysis}

Analyses of variance (ANOVAs) were performed jointly across locations, with genotype and location being considered as fixed effects. Data normality and variance homogeneity were verified before the analysis. For the environments, we performed a Duncan's test to compare means between the environments. Treatment means were grouped using a Scott-Knott test through the ScottKnott package (Jelihovschi et al., 2010). Additionally, the Pearson's correlations among the traits were analyzed using the Hmisc package (Harrell \& Dupont, 2012). For the Pearson correlation analysis for each location, the experiments were considered randomized blocks. However, to obtain the average correlation for the locations a joint analysis was conducted. The significance of the correlations was verified by $t$ test. All procedures were carried out using $R$ software ( $R$ Core Team, 2015).

The graphical analysis of mean production and stability was performed using GGEbiplot software (Yan, 2001), which considers the genotype stability associated with its yield means. The following parameters were used: Data transformation (Transform $=0$, no transformation), data scale (Scaling $=0$, no scale), data centralization (Data centering $=2$, genotype plus genotype $\mathrm{x}$ environment $(G+G E$ ) interaction (GEI)), and singular values partition (SVP $=1$, focus on genotype).

\section{Conclusion}

Protein, oil and fatty acids have significant genotype $x$ environment interaction, highlighting the need to evaluate the performance of cultivars at a wide range of locations. Brazilian soybean presented high oil and protein contents. High oil content promotes the use of the soybean in food and biofuel production. Furthermore, high grain oil content helps effectively concentrate the protein content of the meal produced from Brazilian soybean. This makes the Brazilian soybean meal a standard in the international market. These cultivars have different low concentrations of saturated fatty acids, mainly through reduced palmitic acid content, which makes it suitable for human consumption. Furthermore, Brazilian soybean has low levels of linoleic fatty acid, which provides oxidative stability to the oil, and together with a general low content of polyunsaturated fatty acids is an important feature for biofuels.

\section{Acknowledgement}

The authors would like to thank CNPq and CAPES for financial support, and gratefully acknowledge Dr. CraigDavid Rogers for English revision and for helpful comments.

\section{References}

Bachlava E, Burton JW, Brownie C, Wang S, Auclair J, Cardinal, AJ (2008) Heritability of oleic acid content in soybean seed oil and its genetic correlation with fatty acid and agronomics traits. Crop Sci. 48:1764-1772.

Bellaloui N, Bruns HA, Abbas HK, Mengistu A, Fisher DK, Reddy KN (2015). Agricultural practices altered soybean seed protein, oil, fatty acids, sugars, and minerals in the Midsouth USA. Front plant sci. 6: 1-14.

Bellaloui N, Smith JR, Ray J D, Gillen AM (2009) Effect of maturity on seed composition in the early soybean production system as measured on near-isogenic soybean lines. Crop Sci. 49: 608-620.

Bergmann JC, Tupinambã DD, Costa OYA, Almeida JRM, Barreto CC, Quirino BF (2013) Biodiesel production in Brazil and alternative biomass feedstocks. Renew Sustainable Energy Rev. 21: 411-420. 
Bonato ER, Bertagnolli PF, Lange CE, Rubin SDA (2000) Teor de óleo e de proteína em genótipos de soja desenvolvidos após 1990. PAB. 35: 2391-2398.

Brown-Lima C, Cooney M, Cleary D (2011) An overview of the Brazil-China soybean trade and its strategic implications for conservation. The Nature Conservancy, Latin America Region. Available at: www.nature.org/ourinitiatives/regions/southamerica/braz il/explore/brazil-china-soybean-trade.pdf.

Brumm TJ, Hurburgh CR (1990) Estimating the processed value of soybeans. J Am Oil Chem Soc. 67: 302-307.

Carrera C, Martínez MJ, Dardanelli J, Balzarini M (2011) Environmental variation and correlation of seed components in nontransgenic soybeans: protein, oil, unsaturated fatty acids, tocopherols, and isoflavones. Crop Sci. 51: 800-809.

Castanheira ÉG, Grisoli R, Coelho S, da Silva GA, Freire F (2015) Life-cycle assessment of soybean-based biodiesel in Europe: comparing grain, oil and biodiesel import from Brazil. J Clean Prod. 102: 188-201.

Chang NW, Huang PC (1998) Effects of the ratio of polyunsaturated and monounsaturated fatty acid to saturated fatty acid on rat plasma and liver lipid concentrations. Lipids. 33: 481-487.

Cheesbrough TM (1989) Changes in the enzymes for fatty acid synthesis and desaturation during acclimation of developing soybean seeds to altered growth temperature. Plant Physiol. 90: 760-764.

Chowdhury R, Warnakula S, Kunutsor S, Crowe F, Ward HA, Johnson L, Khaw KT (2014) Association of dietary, circulating, and supplement fatty acids with coronary risk: a systematic review and meta-analysis. Ann Intern Med. 160: 398-406.

Clemente TE, Cahoon EB (2009) Soybean Oil: genetic approaches for modification of functionality and total content. Plant Physiol.151: 1030-1040.

CONAB-Companhia Nacional de Abastecimento. Séries históricas da cultura da Soja (2016) Séries históricas de área plantada, produtividade e produção. Available at: http://www.conab.gov.br/conteudos.php?a=1252\&\&Pagi na_objcmsconteudos=3\#A_objcmsconteudos

Crapiste GH, Brevedan MIV, Carelli AA (1999) Oxidation of sunflower oil during storage. J Am Oil Chem Soc. 76: 14371443.

Dardanelli JL, Balzarini M, Martinez MJ, Cuniberti M, Resnik S, Ramunda SE, Herrero R, Baigorri H (2006) Soybean maturity groups, environments, and their interaction define mega-environments for seed composition in Argentina. Crop Sci. 46: 1939-1947.

Day L (2013) Integrated and comparative proteomics of high-oil and high-protein soybean seeds. Food Sci. 32: 2542.

DiRienzo MA, Lemke SL, Petersen BJ, Smith KM (2008) Effect of substitution of high stearic low linolenic acid soybean oil for hydrogenated soybean oil on fatty acid intake. Lipids. 43: 451-456.

Erdman JW, AHA Nutrition Committee (2000) Soy protein and cardiovascular disease a statement for healthcare professionals from the Nutrition Committee of the AHA. Circulation. 102: 2555-2559.

Fehr WR (2007) Breeding for modified fatty acid composition in soybean. Crop Sci. 47: 72-84.
Ferrari RA, Oliveira VS, Scabio A (2005) Biodiesel de sojataxa de conversão em ésteres etílicos, caracterização físico-química e consumo em gerador de energia. Quím Nova. 28: 19-23.

Grieshop CM, Fahey GC (2001) Comparison of quality characteristics of soybeans from Brazil, China, and the United States. J Agric Food Chem. 49: 2669-2673.

Gunasekera CP, Martin LD, Siddique KHM, Walton GH (2006) Genotype by environment interactions of Indian mustard (Brassica juncea L.) and canola (Brassica napus L.) in Mediterranean-type environments: II. Oil and protein concentrations in seed. Eur J Agr. 25: 13-21.

Han SI, Chae JH, Bilyeu K, Shannon JG, Lee JD (2014) Nondestructive determination of high oleic acid content in single soybean seeds by near infrared reflectance spectroscopy. J Am Oil Chem Soc. 91: 229-234.

Harrell FE, Dupont C (2012) Hmisc: Harrell miscellaneous. R package version 3.9-3. Available at ht tp://CR AN. Rproject. org/package $=$ Hmisc.

Hartwig EE, Hinson K (1972) Association between chemical composition of seed and seed yield of soybeans. Crop Sci. 12: 829-830.

Hemingway J, Eskandari M, Rajcan I (2015) Genetic and environmental effects on fatty acid composition in soybeans with potential use in the automotive industry. Crop Sci. 55: 658-668.

Hu FB, Stampfer MJ, Manson JE, Rimm E, Colditz GA, Rosner BA, Willett WC (1997) Dietary fat intake and the risk of coronary heart disease in women. N Engl J Med. 337: 1491-1499.

Hu M, Wiatrak P (2012) Effect of planting date on soybean growth, yield, and grain quality: Review. Agron J. 104: 785790.

Hymowitz T, Collins Fl, Panczner J, Walker WM (1972) Relationship between the content of oil, protein, and sugar in soybean seed. Agron J. 64: 613-616.

Jelihovschi EG, Faria JC, Allaman IB (2010) The ScottKnott clustering algorithm. UESC, Ilheus, Brazil.

Johnson HW, Robinson HF, Comstock RE (1955) Genotypic and phenotypic correlations in soybeans and these implications in selection. Agron J. 47: 477-483.

Karr-Lilienthal LK, Grieshop CM, Merchen NR., Mahan DC, Fahey GC (2004) Chemical composition and protein quality comparisons of soybeans and soybean meals from five leading soybean-producing countries. J Agric Food Chem. 52: 6193-6199.

Kaya Y, Akçura M, Taner S (2006) GGE-biplot analysis of multi-environment yield trials in bread wheat. Turk J Agric For. 30: 325-337.

Knothe G, Dunn RO (2003) Dependence of oil stability index of fatty compounds on their structure and concentration and presence of metals. J am Oil Chem Soc. 80: 1021-1026.

Knothe G, Matheaus AC, Ryan TW (2003) Cetane numbers of branched and straight-chain fatty esters determined in an ignition quality tester. Fuel. 82: 971-975.

Kumar V, Rani A, Solanki S, Hussain SM (2006) Influence of growing environment on the biochemical composition and physical characteristics of soybean seed. J Food Comp Anal. 19: 188-195.

Kwon SH, Torrie JH (1964) Heritability and interrelationship among traits of two soybean populations. Crop Sci. 4: 196198. 
Lado B, Barrios PG, Quincke M, Silva P, Gutiérrez L (2016) Modeling genotype $\times$ environment interaction for genomic selection with unbalanced data from a breeding program. Crop Sci. 56: 1-15.

Lee JH, Hwang SR, Lee YH, Kim K, Cho KM, Lee YB (2015) Changes occurring in compositions and antioxidant properties of healthy soybean seeds [Glycine max (L.) Merr.] and soybean seeds diseased by Phomopsis longicolla and Cercospora kikuchii fungal pathogens. Food Chem. 185: 205-211.

Mahmoud AA, Natarajan SS, Bennett JO, Mawhinney TP, Wiebold WJ, Krishnan HB (2006) Effect of six decades of selective breeding on soybean protein composition and quality: a biochemical and molecular analysis. J Agric Food Chem. 54: 3916-3922.

Mandarino JMG, Roessing AC, Benassi VT (2005) Óleo: alimentos funcionais. Londrina: Embrapa Soja. 91.

Medic J, Atkinson C, Hurburgh CRJ (2014) Current knowledge in soybean composition. J Am Oil Chem Soc. 91: 363-384.

Meher LC, Sagar DV, Naik SN (2006) Technical aspects of biodiesel production by transesterification-a review. Renew Sustainable Energy Rev. 10: 248-268.

Mounts TL, Warner K, List GR, Kleiman R, Fehr WR, Hammond EG, Wilcox JR (1988) Effect of altered fatty acid composition on soybean oil stability. J Am Oil Chem Soc. 65: 624-628.

Mourya V, Kumar V, Rani A, Jain M, Husain SM (2016) NearInfrared Reflectance spectroscopy for protein content in soybean flour and screening of germplasm across different countries. Agr Res. 5: 29-34.

Naeve SL, Huerd SC (2008) Year, region, and temperature effects on the quality of Minnesota's soybean crop. Agron J. 100: 690-695.

Ohlrogge J, Browse J (1995) Lipid biosynthesis. Plant Cell. 7: 957-970.

Oliva ML, Shannon JG, Sleper DA, Ellersieck MR, Cardinal AJ, Paris RL, Lee JD (2006) Stability of fatty acid profile in soybean genotypes with modified seed oil composition. Crop Sci. 46: 2069-2075.

Peel MC, Finlayson BL, Mcmahon TA (2007) Updated world map of the Köppen-Geiger climate classification. Hydrol Earth Syst Sc. 1: 1633-1644

Pinzi S, Rounce P, Herreros JM, Tsolakis A, Dorado MP (2013) The effect of biodiesel fatty acid composition on combustion and diesel engine exhaust emissions. Fuel. 104: 170-182.

Pípolo AE (2002) Influência da temperatura sobre as concentrações de proteínas e óleo em sementes de soja (Glycine max (L.) Merrill). Thesis (PhD in Agronomy) Escola Superior de Agricultura "Luiz de Queiroz", Universidade de São Paulo, Piracicaba. 128 pages.

Popovic V, Vidic M, Jockovic D, Ikanovic J, Jaksic S, Cvijanovic G (2012) Variability and correlations between yield components of soybean Glycine max (L.) Merr. Genetika. 44: 33-45.

Priolli RHG, Campos JB, Stabellini NS, Pinheiro JB, Vello NA (2015) Association mapping of oil content and fatty acid components in soybean. Euphytica. 203: 83-96.

Ramos MJ, Fernández CM, Casas A, Rodríguez L, Pérez Á (2009) Influence of fatty acid composition of raw materials on biodiesel properties. Bioresour Technol. 100: 261-268.
Ren C, Bilyeu KD, Beuselinck PR (2009) Composition, vigor, and proteome of mature soybean seeds developed under high temperature. Crop Sci. 49: 1010-1022.

Rotundo JL, Westgate ME (2009) Meta-analysis of environmental effects on soybean seed composition. Field Crop Res. 110: 147-156.

Rotundo JL, Borrás L, De Bruin J, Pedersen P (2014) Soybean nitrogen uptake and utilization in Argentina and United States cultivars. Crop Sci. 54: 1153-1165.

Rotundo JL, Miller-Garvin JE, Naeve SL (2016) Regional and temporal variation in soybean seed protein and oil across the united states. Crop Sci. 56: 797-808.

Santos EM, Piovesan ND, de Barros EG, Moreira MA (2013) Low linolenic soybeans for biodiesel: characteristics, performance and advantages. Fuel. 104: 861-864.

Sarkar A, Golay PA, Acquistapace S, Craft BD (2015) Increasing the oxidative stability of soybean oil through fortification with antioxidants. Int J Food Sci Tech. 50: 666673.

Schwender J, Ohlrogge JB, Shachar-Hill Y (2003) A flux model of glycolysis and the oxidative pentosephosphate pathway in developing Brassica napus embryos. J Biol Chem. 278: 29442-29453.

Sharma M, Ghosh R, Telangre R, Rathore A, Saifulla $M$, Mahalinga DM, Jain YK (2016) Environmental influences on Pigeonpea-Fusarium udum interactions and stability of genotypes to Fusarium Wilt. Front Plant Sci. 7: 253.

Simpson Junior AM, Wilcox JR (1983) Genetic and phenotypic associations of agronomic characteristics in four high protein soybean populations. Crop Sci. 23: 10771081.

Song JY, Piao XM, Choi YM, Lee GA, Chung JW, Lee JR, Jung Y, Park HJ, Lee MC (2013) Evaluation of genetic diversity and comparison of biochemical traits of soybean (Glycine max L.) germplasm collections. Plant Breed Biotechnol. 4: 374- 384.

Song $W$, Yang $R$, Wu T, Wu C, Sun S, Zhang $S$, Zhang $C$, Jiang B, Tian S, Liu X, Han T (2016) Analyzing the effects of climate factors on soybean protein, oil contents, and composition by extensive and high-density sampling in China. J Agric Food Chem. 64: 4121-4130.

Stanojevic SP, Barac MB, Pesic MB, Radovic VV (2011) Assessment of soy genotype and processing method on quality of soybean tofu. J Agric Food Chem. 59: 7368-7376.

Stoltzfus DL, Fehr WR, Welke GR (2000) Relationship of elevated palmitate to soybean seed traits. Crop Sci, 40: 52-54.

Tang GQ, Novitzky WP, Carol Griffin H, Huber SC, Dewey RE (2005) Oleate desaturase enzymes of soybean: evidence of regulation through differential stability and phosphorylation. Plant J. 44: 433-446.

Team RC (2015) R: A language and environment for statistical computing. Vienna, Austria: R Foundation for Statistical Computing; $R$ Foundation for Statistical Computing.

Thakur M, Hurburgh CR (2007) Quality of US soybean meal compared to the quality of soybean meal from other origins. J Am Oil Chem Soc. 84: 835-843.

Thelen JJ, Ohlrogge JB (2002) Metabolic Engineering of Fatty Acid Biosynthesis in plants. Metab Eng. 4: 12-21.

Thomas AL, Guerreiro SMC, Sodek L (2005) Aerenchyma formation and recovery from hypoxia of the flooded root system of nodulated soybean. Ann Bot. 96: 1191-1198. 
Thorne JC, Fehr WR (1970) Incorporation of high protein, exotic germplasm into soybean populations by 2- and 3way crosses. Crop Sci. 10: 652-655.

United States Department of Agriculture (USDA). Available at:

http://apps.fas.usda.gov/psdonline/circulars/oilseeds.pdf. Acessed: 08 out. 2016.

Vieira CR, Cabral LC, Paula AD (1999) Composição centesimal e conteúdo de aminoácidos, ácidos graxos e minerais de seis cultivares de soja destinadas à alimentação humana. PAB. 34: 1277-1283.

Voldeng HD, Cober ER, Hume DJ, Gillard C, Morrison MJ (1997) Fifty-eight years of genetic improvement of shortseason soybean cultivars in Canada. Crop Sci. 37: 428-431.

Vollmann J, Fritz CN, Wagentristl H, Ruckenbauer P (2000) Environmental and genetic variation of soybean seed protein content under Central European growing conditions. J Sci Food Agr. 80: 1300-1306.

Wang R, Chen Y, Ren J, Guo S (2014) Aroma stability of millet powder during storage and effects of cooking methods and antioxidant treatment. Cereal Chem. 91: 262-269.

Wilcox JR, Cavins JF (1992) Normal and low linolenic acid soybean strains: Response to planting date. Crop Sci. 32: 1248-1251.

Wilcox JR, Guodong Z (1997) Relationship between seed yield and seed protein in determinate and indeterminate soybean populations. Crop Sci. 37: 361-364.

Willett WC, Ascherio A (1994) Trans fatty acids: are the effects only marginal? Am J Public Health. 84: 722-724.
Wilson RF (2004) Seed composition. Soybeans: improvement, production, and uses, (soybeansimprove), 621-677.

Wilson RF, Burton JW, Pantalone VR (2002) New gene combinations governing saturated and unsaturated fatty acid. Lipid Biotechnol. 95-114.

Wittkop B, Snowdon RJ, Friedt W (2009) Status and perspectives of breeding for enhanced yield and quality of oilseed crops for Europe. Euphytica. 170: 131-140.

Wolf RB, Cavins JF, Kleiman R, Black LT (1982) Effect of temperature on soybean seed constituents: oil, protein, moisture, fatty acids, amino acids and sugars. J Am Oil Chem Soc. 59: 230-232.

Wu H, Zhang J, Wei Q, Zheng J, Zhang J (2013) Transesterification of soybean oil to biodiesel using zeolite supported $\mathrm{CaO}$ as Strong base catalysts. Fuel Process Technol. 109: 13-18.

Yan W (2001) GGEbiplot-a Windows application for graphical analysis of multi-environment trial data and other types of two-way data. Agron J. 93: 1111-1118.

Yan W, Kang MS, Ma B, Woods S, Cornelius PL (2007) GGE biplot vs. AMMI analysis of genotype-by-environment data. Crop Sci. 47: 643-653.

Zhang A, Liu X, Wang G, Wang $H$, Liu J, Zhao W, Zhang $Y$ (2015) Crude fat content and fatty acid profile and their correlations in foxtail millet. Cereal Chem. 92: 455-459.

Zhe Y, Lauer JG, Borges R, De Leon N (2010) Effects of genotype $\times$ environment interaction on agronomic traits in soybean. Crop Sci. 50: 696-702. 